\title{
The negative impact of Alagille syndrome on survival of infants with pulmonary atresia
}

Gillian M. Blue, MSci, ${ }^{a, b}$ Jean M. Mah, MBBS, ${ }^{c}$ Andrew D. Cole, BAppSci, ${ }^{a}$ Vanita Lal, PhD, ${ }^{a}$

Meredith J. Wilson, MBBS, FRACP, MBioeth, ${ }^{\text {b }}$ Richard B. Chard, BDS, MBBS, FRACS, ${ }^{\mathrm{a}, \mathrm{c}}$

Gary F. Sholler, MBBS, FRACP, ${ }^{a, c}$ Richard E. Hawker, MBBS, FRACP, ${ }^{a}$ Megan C. Sherwood, MBBS, FRACP, ${ }^{a, c}$ and

David S. Winlaw, MD, FRACS, ${ }^{\text {a,c }}$ Sydney, Australia

From the Kids Heart Research and Adolph Basser Cardiac Institute, ${ }^{\mathrm{a}}$ Department of Clinical Genetics, ${ }^{\mathrm{b}}$ Discipline of Paediatrics and Child Health, Faculty of Medicine, University of Sydney, ${ }^{\mathfrak{c}}$ The Children's Hospital at Westmead, Sydney, Australia.

Received for publication Dec 12, 2006; accepted for publication Dec 18, 2006.

Address for reprints: Dr David Winlaw, Paediatric Cardiac Surgeon, Head, Kids Heart Research, The Children's Hospital at Westmead, Locked Bag 4001, Westmead NSW 2145, Australia (E-mail: davidw@ chw.edu.au).

J Thorac Cardiovasc Surg 2007;133:1094-6

$0022-5223 / \$ 32.00$

Copyright $\odot 2007$ by The American Association for Thoracic Surgery

doi:10.1016/j.jtcvs.2006.12.009
A lagille syndrome (AGS) is a complex disorder with multisystemic involvement, including the liver, heart, kidneys, cerebral vasculature, skeleton, eyes, and face. ${ }^{1}$ A structural heart defect is one of the diagnostic criteria for AGS. These vary in severity, with peripheral pulmonary arterial stenosis being a common problem. Pulmonary atresia (PA) is a rare presentation in AGS, but we were impressed by the poor outcome of such infants following review of our institutional experience over the last 20 years. The information has particular relevance in this era where prenatal diagnosis of both AGS and PA can be made.

\section{Clinical Summary}

A number of information sources including cardiac, genetic, and gastroenterology departmental databases and hospital medical

TABLE 1. Clinical summary, surgical procedures, and outcomes in 5 cases presenting with Alagille syndrome and pulmonary atresia between 1985 and 2005

\begin{tabular}{|c|c|c|c|c|}
\hline $\begin{array}{l}\text { Patient } \\
\text { (gender) }\end{array}$ & $\begin{array}{l}\text { Born/status/age } \\
\text { at last follow-up }\end{array}$ & Cardiac lesions & Alagille-specific features & Genetics/family history \\
\hline 1 (M) & 2003/alive/2.5 y & $\begin{array}{l}\text { PA/VSD/PAH with minor } \\
\text { collaterals }\end{array}$ & $\begin{array}{l}\text { Jaundice, butterfly vertebra, } \\
\text { radioulnar synostosis, mild } \\
\text { facial dysmorphism }\end{array}$ & $\begin{array}{l}\text { JAG1 mutation/mother and } \\
\text { maternal aunt have mutation } \\
\text { and mild cardiac problems, } \\
\text { maternal cousin has CHD }\end{array}$ \\
\hline $2(\mathrm{M})$ & $2002 /$ dead/2.5 y & $\begin{array}{l}\text { PA/IVS/PAH with } \\
\text { MAPCAs }\end{array}$ & $\begin{array}{l}\text { Butterfly vertebra, pointed chin, } \\
\text { high forehead, bilateral } \\
\text { Axenfeld-Reiger anomaly }\end{array}$ & $\begin{array}{l}\text { JAG1 mutation/father has heart } \\
\text { murmur, paternal grandfather } \\
\text { has had mitral valve } \\
\text { replacement, no family gene } \\
\text { testing }\end{array}$ \\
\hline $3(\mathrm{M})$ & 1995/dead/2.5 y & TOF/PAH & $\begin{array}{l}\text { Decreased bile ducts, prominent } \\
\text { forehead, pointed chin }\end{array}$ & $\begin{array}{l}\text { No testing/father has TOF, } 2 \\
\text { siblings have pulmonary } \\
\text { valve stenosis }\end{array}$ \\
\hline $4(F)$ & 1987/dead/5.5 y & $\begin{array}{l}\text { PA/VSD/PAH with } \\
\text { MAPCAs }\end{array}$ & $\begin{array}{l}\text { Paucity of intrahepatic bile ducts, } \\
\text { frontal bossing, small mandible, } \\
\text { butterfly vertebra, global DD }\end{array}$ & $\begin{array}{l}\text { No testing/no mention of } \\
\text { similar conditions in } \\
\text { immediate or extended family } \\
\text { members }\end{array}$ \\
\hline $5(\mathrm{M})$ & 1976/dead/20 y & $\begin{array}{l}\text { PA/VSD/PAH with } \\
\text { MAPCAs }\end{array}$ & $\begin{array}{l}\text { Thickened portal tracts, butterfly } \\
\text { vertebrae, prominent forehead, } \\
\text { pointed chin }\end{array}$ & $\begin{array}{l}\text { No testing/no mention of } \\
\text { similar conditions in } \\
\text { immediate or extended family } \\
\text { members }\end{array}$ \\
\hline
\end{tabular}

PA, pulmonary atresia; VSD, ventricular septal defect; IVS, intact ventricular septum; $P A H$, pulmonary artery hypoplasia; TOF, tetralogy of Fallot; $M A P C A s$, major aortopulmonary collateral arteries; $D D$, developmental delay; $C H D$, congenital heart disease; $D U A$, death under anesthesia; $R V$, right ventricle. 
records were searched and cross-referenced to identify patients with AGS and/or PA between 1985 and 2004. We identified 26 patients with AGS and 505 patients with PA, 5 of whom had both diagnoses. Patients with AGS and only peripheral pulmonary arterial stenoses were excluded. Our institution serves a population of more than 6 million people, performs more than 400 cardiac procedures annually, and has a raw operative mortality of $<2 \%$.

Five cases of AGS with PA were identified (see Table 1): 4 with PA and ventricular septal defect (VSD), 1 with PA and intact ventricular septum. Four of 5 patients $(80 \%)$ have died as a result of cardiac disease, and the remaining individual is receiving palliative management.

The most striking feature is the failure of small pulmonary arteries to grow following systemic-to-pulmonary arterial shunts. In 3 patients, collateral pulmonary blood flow was deemed sufficient to allow delay in initial surgery for more than 6 months. Where pulmonary arteries have been considered to be borderline adequate, establishment of a pulmonary arterial confluence and/or biventricular repair have not been successful.

\section{Discussion}

AGS is an autosomal-dominant disorder caused by mutations or deletions in the JAG1 gene, located on chromosome 20p11.2-20p12. The JAG1 gene produces a protein, Jagged1, which is an important ligand in the $\mathrm{NOTCH}$ signaling pathway and plays an important role in early cell determination. ${ }^{2}$ The expression of Jaggedl within the developing embryo of both mice and humans correlates with cardiovascular disease in AGS. ${ }^{3}$ Expression is primarily seen in structures destined to become part of the right-sided circulatory system, including the sixth pharyngeal arch, which gives rise to the pulmonary artery, as well as in the pulmonary outflow tract. No clear genotypephenotype correlations have yet been established to account for the high degree of variability of both the number and the extent to which the various organ systems are involved. In a study of monozygotic twins with an identical splice site mutation in JAG1, 1 twin had PA and the other had only mild cardiac disease but more severe hepatic involvement. ${ }^{4}$ Although it is recognized that mutations or deletions in JAG1 cause AGS, other factors including environmental triggers, modifying genetic loci, and epigenetic factors may contribute to the phenotype of an individual, as is the case in many other forms of structural heart disease.

Cardiac disease significantly impacts on the life expectancy of patients with AGS and accounts for $34 \%$ of mortality. ${ }^{1}$ PA alone, with or without a VSD, is a serious condition; however, with contemporary surgical techniques, most patients survive infancy, with an increasing number expected to achieve biventricular repair. ${ }^{1}$ It is not clear why the patients with AGS who received systemic-to-pulmonary shunts did not show evidence of pulmonary arterial growth. In the 3 who had generous collateral flow, initial palliation was deferred, but in the current

\section{TABLE 1. Continued}

\begin{tabular}{|c|c|c|c|c|}
\hline $\begin{array}{c}\text { 1st surgery age/ } \\
\text { description }\end{array}$ & 2nd surgery age/description & $\begin{array}{c}\text { 3rd surgery } \\
\text { age/description }\end{array}$ & $\begin{array}{l}\text { 4th surgery } \\
\text { age/description }\end{array}$ & Comments \\
\hline $\begin{array}{l}9 \mathrm{~d} / \text { central } \\
\text { shunt }(4 \mathrm{~mm})\end{array}$ & $\begin{array}{l}4 \text { mo/augment central shunt } \\
\text { ( } 5 \mathrm{~mm}) \text { utilizing } \\
\text { cardiopulmonary bypass }\end{array}$ & $\begin{array}{l}1 \text { y } 1 \mathrm{mo} / \text { modified } \\
\text { right Blalock shunt } \\
(4 \mathrm{~mm})\end{array}$ & $\begin{array}{l}1 \text { y } 10 \mathrm{mo} / \text { modified } \\
\text { left Blalock } \\
\text { shunt }(5 \mathrm{~mm})\end{array}$ & $\begin{array}{l}\text { Failure of pulmonary arteries to } \\
\text { grow despite augmentation of } \\
\text { pulmonary blood flow }\end{array}$ \\
\hline $\begin{array}{l}27 \mathrm{~d} / \text { pulmonary } \\
\text { valve balloon } \\
\text { dilation }\end{array}$ & $\begin{array}{l}3 \text { mo/modified right Blalock } \\
\text { shunt }(4 \mathrm{~mm})\end{array}$ & - & - & $\begin{array}{l}\text { Extremely hypoplastic pulmonary } \\
\text { arteries despite shunt; no } \\
\text { further surgery undertaken }\end{array}$ \\
\hline $\begin{array}{l}6 \text { mo } 19 \\
\text { d/central } \\
\text { shunt }(4 \mathrm{~mm})\end{array}$ & $\begin{array}{l}6 \mathrm{mo} 20 \mathrm{~d} / \text { left Blalock shunt } \\
(5 \mathrm{~mm})\end{array}$ & $\begin{array}{l}2 \text { y } 3 \text { mo/attempted } \\
\text { biventricular repair } \\
\text { with RV-PA } \\
\text { conduit }\end{array}$ & - & $\begin{array}{l}\text { Initial shunt blocked; following } \\
\text { repair, high RV pressures, VSD } \\
\text { patch fenestrated; DUA }\end{array}$ \\
\hline $\begin{array}{l}9 \text { mo/left } \\
\text { Blalock } \\
\text { shunt }(5 \mathrm{~mm})\end{array}$ & $\begin{array}{l}1 \text { y } 8 \text { mo/recruitment } \\
\text { MAPCAs and right } \\
\text { Blalock shunt }(5 \mathrm{~mm})\end{array}$ & $\begin{array}{l}5 \text { y } 7 \text { mo/attempted } \\
\text { establishment of } \\
\text { pulmonary arterial } \\
\text { continuity }\end{array}$ & 一 & $\begin{array}{l}\text { Difficulty establishing satisfactory } \\
\text { pulmonary artery confluence; } \\
\text { attempted bilateral systemic- } \\
\text { pulmonary shunt without RV to } \\
\text { pulmonary artery conduit; DUA }\end{array}$ \\
\hline $\begin{array}{l}6 \text { y } 3 \mathrm{mo} / \text { right } \\
\text { Blalock } \\
\text { shunt }(5 \mathrm{~mm})\end{array}$ & $\begin{array}{l}14 \text { y } 7 \text { mo/recruitment of } \\
\text { MAPCAs, left Blalock } \\
\text { shunt }(6 \mathrm{~mm})\end{array}$ & $\begin{array}{l}14 \text { y } 8 \text { mo/pericardial } \\
\text { drainage }\end{array}$ & - & $\begin{array}{l}\text { Difficulties recruiting MAPCAs, } \\
\text { coagulopathy from liver } \\
\text { disease and aortic } \\
\text { incompetence; further surgery } \\
\text { not offered }\end{array}$ \\
\hline
\end{tabular}


era we would aim to augment pulmonary blood flow as soon as possible to achieve what pulmonary arterial growth is possible. Unfortunately, even when this approach was aggressively employed (case 1), satisfactory pulmonary vascular development has not been achieved.

Our study expands on a theme identified by McElhinney and colleagues, ${ }^{2}$ who noted that patients with a JAG1 mutation and PA/VSD had a poor outcome, with 6 of 8 patients (75\%) not surviving treatment in infancy. The survival rate in their patient group mirrors that of our cohort and highlights the severity of the condition. These results have implications for clinical decision making and management of PA in the context of AGS and allow us to calibrate expectations for those requiring surgery.

We acknowledge the contributions of Prof Tim Cartmill, Dr David Johnson, Dr Graham Nunn, Dr Ian Nicholson, and Dr Stephen Cooper, who were involved in the clinical management of these patients.

\section{References}

1. Kamath BM, Spinner NB, Emerick KM, Chudley AE, Booth C, Piccoli DA, et al. Vascular anomalies in Alagille syndrome: a significant cause of morbidity and mortality. Circulation. 2004;109:1354-8.

2. McElhinney DB, Krantz ID, Bason L, Piccoli DA, Emerick KM, Spinner NB, et al. Analysis of cardiovascular phenotype and genotypephenotype correlation in individuals with a JAG1 mutation and/or Alagille syndrome. Circulation. 2002;106:2567-74.

3. Loomes KM, Underkoffler LA, Morabito J, Gottlieb S, Piccoli DA, Spinner NB, et al. The expression of Jaggedl in the developing mammalian heart correlates with cardiovascular disease in Alagille syndrome. Hum Mol Genet. 1999;8:2443-9.

4. Kamath BM, Krantz ID, Spinner NB, Heubi JE, Piccoli DA. Monozygotic twins with a severe form of Alagille syndrome and phenotypic discordance. Am J Med Genet. 2002;112:194-7.

5. Reddy VM, McElhinney DB, Amin Z, Moore P, Parry AJ, Teitel DF, et al. Early and intermediate outcomes after repair of pulmonary atresia with ventricular septal defect and major aortopulmonary collateral arteries: experience with 85 patients. Circulation. 2000; 101:1826-32.

\title{
Infant arch reconstruction during total system perfusion
}

\author{
Aimee B. Gardner, BS, CCP, and Pirooz Eghtesady, MD, PhD, Cincinnati, Ohio
}

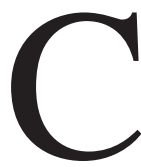

urrently, neonatal arch reconstruction requires the use of circulatory arrest or, predominantly, regional cerebral perfusion techniques. ${ }^{1}$ With regional perfusion, the question remains as to the adequacy of brain perfusion. ${ }^{2,3}$ Recent clinical and experimental evidence suggests that, with all techniques, systemic perfusion is sacrificed and unwanted effects of deep hypothermia remain. With the use of the INVOS cerebral oximeter (Somanetics, Troy, Mich), changes in the regional cerebral oxygen saturation are now noninvasively and continuously monitored, allowing for the comparison of different techniques. We present a case of successful aortic arch reconstruction in an infant using a novel technique that allows total cerebral as well as systemic perfusion during arch reconstruction.

\section{Clinical Summary}

A 6-month-old infant with Shone's anomaly, who had undergone a previous repair of coarctation of aorta and total anomalous

From the Cincinnati Children's Hospital Medical Center, Cincinnati, Ohio. Received for publication Oct 25, 2006; accepted for publication Oct 30, 2006.

Address for reprints: Aimee B. Gardner, BS, CCP, Cincinnati Children's Hospital Medical Center, Cardiothoracic Surgery, 3333 Burnet Ave, MLC 2004, Cincinnati OH 45229 (E-mail: Aimee.gardner@cchmc.org).

J Thorac Cardiovasc Surg 2007;133:1096-8

$0022-5223 / \$ 32.00$

Copyright @ 2007 by The American Association for Thoracic Surgery doi:10.1016/j.jtcvs.2006.10.072 pulmonary venous return, developed a new arch that narrowed between the innominate artery and left carotid takeoff. Because of worsening left ventricular hypertrophy, increased left ventricular end diastolic pressure, and a mild increase in right-sided pressures, reintervention was recommended.

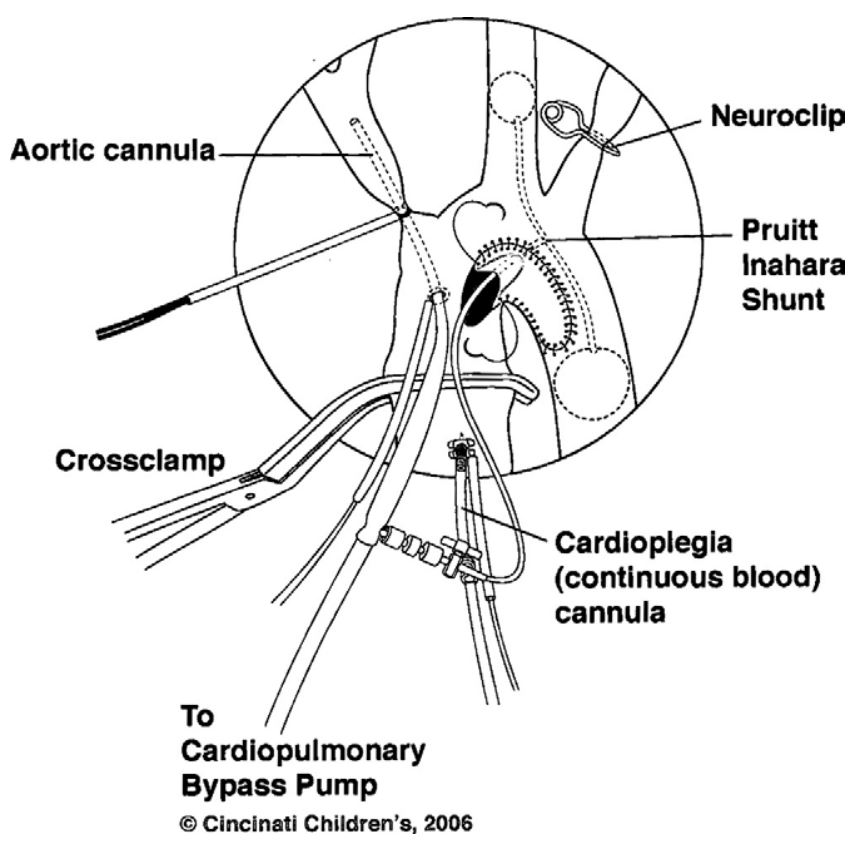

Figure 1. Positioning of Pruitt-Inahara shunt for aortic arch repair. CPB, cardiopulmonary bypass. 